\title{
Hexaconazole foliar application alleviates water deficit effects in common bean ${ }^{1}$
}

\author{
Nasim Chehelpar ${ }^{2}$, Hamid Reza Tohidi-Moghadam² ${ }^{2}$ Farshad Ghoushchi ${ }^{2}$
}

\section{ABSTRACT}

Currently, the world is facing many problems of crop production. Among them, water deficit is the most dangerous one. This study aimed at evaluating the possibility of enhancing the water deficit tolerance of common bean plants, during two growth stages, by the exogenous application of hexaconazole. The experimental design was completely randomized, in a factorial arrangement, with three replicates. Hexaconazole $\left(0 \mathrm{mg} \mathrm{L}^{-1}, 10 \mathrm{mg} \mathrm{L}^{-1}\right.$ and $\left.20 \mathrm{mg} \mathrm{L}^{-1}\right)$ was sprayed at flowering (R3), at 60 days after sowing, and at the grain-filling stage (R8), at 90 days after sowing. After the application, the plants were subjected to water deficit by withholding irrigation for seven days. Although all hexaconazole concentrations improved the water deficit tolerance in bean plants, in terms of plant growth and yield, the application of $20 \mathrm{mg} \mathrm{L}^{-1}$ provided a better protection, when compared to the other concentrations $(\mathrm{p}<0.01)$. The exogenous application of hexaconazole improved the water deficit tolerance, if compared to non-treated plants, affecting the morphological characteristics, yield components, total chlorophyll, proline, relative water content and enzymatic antioxidants $(\mathrm{p}<0.01)$. The results showed that the hexaconazole-induced tolerance to water deficit in common bean is related to changes in the growth variables and antioxidants. In conclusion, the hexaconazole application could improve the bean growth and yield under water deficit conditions.

KEY-WORDS: Phaseolus vulgaris L.; proline; grain yield components; antioxidants.

\section{INTRODUCTION}

Water deficit is one of the most important abiotic stresses and is generally accompanied by heat stress, in arid and semi-arid regions (Dash \& Mohanty 2001). Drought is responsible for decreasing crop yield worldwide. Therefore, the accurate identification of the critical irrigation timing is crucial for conserving water and improving the irrigation performance (Ngouajio et al. 2007).

\section{RESUMO}

Aplicação foliar de hexaconazol

ameniza efeitos de déficit hídrico em feijoeiro

Atualmente, o mundo está enfrentando muitos problemas, com relação à produtividade de safras. Dentre eles, o déficit hídrico é o mais ameaçador. Avaliou-se a possibilidade de aumentar a tolerância de feijoeiro ao déficit hídrico, durante dois estágios de crescimento, por meio da aplicação exógena de hexaconazole. O delineamento experimental foi inteiramente casualizado, em esquema fatorial, com três repetições. Hexaconazole $\left(0 \mathrm{mg} \mathrm{L}^{-1}, 10 \mathrm{mg} \mathrm{L}^{-1}\right.$ e $\left.20 \mathrm{mg} \mathrm{L}^{-1}\right)$ foi pulverizado na floração (R3), aos 60 dias após a semeadura, e no enchimento de grãos (R8), aos 90 dias após a semeadura. Após a aplicação, as plantas foram submetidas a deficiência hídrica, pela supressão da irrigação por sete dias. Apesar de todas as concentrações de hexaconazole terem melhorado a tolerância à deficiência hídrica, em plantas de feijão, a aplicação de $20 \mathrm{mg} \mathrm{L}^{-1}$ proporcionou melhor proteção, em comparação com as outras concentrações ( $p<0,01)$. A aplicação exógena de hexaconazole melhorou a tolerância ao déficit hídrico, em relação a plantas não tratadas com hexaconazole, afetando as características morfológicas, componentes de produtividade, clorofila total, prolina, teor relativo de água e antioxidantes enzimáticos $(\mathrm{p}<0,01)$. Os resultados mostraram que a tolerância ao déficit hídrico induzida por hexaconazole, em feijoeiro, está relacionada com as alterações nas variáveis de crescimento e antioxidantes. Em conclusão, a aplicação de hexaconazole poderia melhorar o crescimento e o rendimento do feijoeiro sob condições de déficit hídrico.

PALAVRAS-CHAVE: Phaseolus vulgaris L.; prolina; componentes de rendimento de grãos; antioxidantes.

Water deficit disturbs crop physiology, causing a large number of changes in plant morphology, biochemistry and anatomy. These changes have an extensive effect on crop growth and yield (Reisdorph \& Koster 1999), and the extent of the negative impact is known to be genotypedependent (Bannayan et al. 2008). Plants can respond and adapt to water stress by altering their cellular metabolism and triggering various defence mechanisms (Bohnert \& Jensen 1996). Water deficit 
leads to oxidative stress in plant cells, due to a higher leakage of electrons toward $\mathrm{O}_{2}$, during the photosynthetic and respiratory processes, leading to enhancement in reactive oxygen species (Ahmad et al. 2010, Sánchez-Rodríguez et al. 2012). Reactive oxygen species, such as superoxide anion $\left(\mathrm{O}_{2}^{-}\right)$, hydrogen peroxide $\left(\mathrm{H}_{2} \mathrm{O}_{2}\right)$, hydroxyl radical $\left(\mathrm{HO}^{-}\right)$ and singlet oxygen $\left({ }^{1} \mathrm{O}_{2}\right)$, are damageable for cellular structures and macromolecules, causing photoinhibition of the photosynthetic apparatus (Ahmad et al. 2011). In addition, it can directly damage membrane lipids, inactivate metabolic enzymes and damage nucleic acids, leading to cell death (Ahmad et al. 2011).

Several attempts have been made to alleviate the adverse effects of water deficit on plants. For instance, plant growth regulators have been applied as a means of improving plant growth. It has been reported that the proper application of plant growth regulators may increase the plant tolerance to environmental stresses such as drought, heavy metals, salinity, chilling and water-logging (Hayat et al. 2007, Hasan et al. 2008).

Hexaconazole $\left(\mathrm{C}_{14} \mathrm{H}_{17} \mathrm{Cl}_{2} \mathrm{~N}_{3} \mathrm{O}\right)$ is a systemic fungicide from the triazole family used to control many fungi, particularly Ascomycetes and Basidiomycetes. It exhibits plant growth regulation properties (Fletcher et al. 2000) and induces many morphological and physiological changes in plants (Jaleel et al. 2007).

The application of ketoconazole and uniconazole, a closely related triazole, enhances the tolerance to stresses induced by salinity and water logging (Tan et al. 2006), heat (Reddy et al. 2004) and freezing (Manivannan et al. 2007). Triazole compounds have been shown to improve the tolerance of stressed plants, possibly due to an improved antioxidative defense mechanism, by inducing higher activities of superoxide dismutase and peroxidase (Leul \& Zhou 1999).

Common bean is one of the most important food legumes for human consumption (Makunde \& Pompi 2004). With over $25 \%$ of proteins in the grains, common bean is a major source of proteins in human diets. Beans are also one of the best nonmeat sources of iron, providing $23-30 \%$ of the dailyrecommended levels from a single serving (Schwarts et al. 1996). However, water deficit is a major abiotic factor that threats the common bean production. So, to improve agricultural productivity within limited land and water resources, it is imperative to ensure high crop yields against unfavorable environmental stresses.

Therefore, this study aimed at understanding the ability of hexaconazole to alleviate water deficit in common bean plants, with an emphasis on growth, yield, physiological and biochemical changes.

\section{MATERIAL AND METHODS}

In order to evaluate the effects of hexaconazole foliar application on quantitative and qualitative characteristics of common bean, a two-year experiment was conducted in 2014 and 2015, in Varamin, Iran $\left(51^{\circ} 38^{\prime} \mathrm{E}, 35^{\circ} 19^{\prime} \mathrm{N}\right.$ and $921 \mathrm{~m}$ of altitude). The water deficit at flowering (R3), at 60 days after sowing (DAS), and at the grain-filling stage (R8), at $90 \mathrm{DAS}$, were evaluated. Hexaconazole $\left(0 \mathrm{mg} \mathrm{L}^{-1}, 10 \mathrm{mg} \mathrm{L}^{-1}\right.$ and $20 \mathrm{mg} \mathrm{L}^{-1}$ ) was tested in a completely randomized design, in a factorial (2 stages x 3 hexaconazole concentrations) arrangement, with three replicates. Common bean cv. Goli seeds were disinfected by soaking in $0.5 \%$ of $\mathrm{NaCIO}_{3}$, for $5 \mathrm{~min}$, and then washed with sterile distilled water three times, under a laminar flow cabinet. Ten seeds were placed in $30 \mathrm{~cm} \times 30 \mathrm{~cm}$ plastic pots filled with $3 \mathrm{~kg}$ of a soil mixture composed of field soil, sand and farmyard manure $(1: 1: 1, \mathrm{v} / \mathrm{v} / \mathrm{v})$, with a bulk density of $1.28 \mathrm{~g} \mathrm{~cm}^{-3}$.

The pots were placed in a phytotron (LGC, 5301, Lab Tech, South Korea) with photosynthetically active radiation of $350 \mu \mathrm{mol} \mathrm{m} \mathrm{m}^{-2} \mathrm{~s}^{-1}$, room air temperature of $25 / 20{ }^{\circ} \mathrm{C}$, during the light/dark photoperiod of $16 / 8 \mathrm{~h}$. Relative humidity was adjusted to $65 \%$. Timers, pipes and drippers $\left(4 \mathrm{~L} \mathrm{~h}^{-1}\right)$ were installed to control the irrigation water volume and irrigation intervals. The pots were irrigated until the soil water content reached field capacity. Soil water content at field capacity was defined as the no water deficit control treatment. Time-domain reflectometer probes (TRIME-FM, England) were used to measure the soil water content in each pot. Data on soil volumetric water content were collected daily to calculate the field capacity.

At 15 DAS, five seedlings of uniform size were left to grow in each pot. Hexaconazole ( $0 \mathrm{mg} \mathrm{L}^{-1}, 10 \mathrm{mg} \mathrm{L}^{-1}$ and $20 \mathrm{mg} \mathrm{L}^{-1}$ ) was sprayed on the plants at R3 and R8. Each pot was sprayed once with hexaconazole solutions supplied with $0.1 \%$ (v/v) Tween 20 as surfactant, using a hand-held 
aerosol-propelled sprayer. The pots for $0 \mathrm{mg} \mathrm{L}^{-1}$ hexaconazole treatments received water and Tween 20. After hexaconazole application, the plants were subjected to water deficit by withholding irrigation until the soil water content declined to $20 \%$ of field capacity. On the seventh day, tissue samples were collected to measure chlorophyll, relative water content and proline, as well as antioxidant enzyme activity, such as superoxide dismutase, peroxidase and catalase. Chlorophyll was extracted from the leaves and measured according to Arnon (1949). A leaf sample of $100 \mathrm{mg}$ was suspended in $10 \mathrm{~mL}$ of $80 \%$ acetone, mixed and kept at $4{ }^{\circ} \mathrm{C}$ overnight in the dark. The supernatant was withdrawn after centrifugation $(5,000 \mathrm{rmp})$ and absorbance was recorded at $663 \mathrm{~nm}$ and $645 \mathrm{~nm}$, using a spectrophotometer (Cintra GBC, Dandenong, Victoria, Australia).

Free proline was determined from the leaf samples (Bates et al. 1973). A 1:1:1 solution of proline, ninhydrin acid and glacial acetic acid was incubated at $100{ }^{\circ} \mathrm{C}$, for $1 \mathrm{~h}$. The reaction was sitting in an iced bath and the chromophore was extracted with $4 \mathrm{~mL}$ of toluene, and its absorbance at $520 \mathrm{~nm}$ was determined using a spectrophotometer.

Catalase activity was estimated according to Cakmak \& Horst (1991). The reaction mixture contained $100 \mu \mathrm{L}$ of crude extract, $500 \mu \mathrm{L} 10 \mathrm{~mm}$ of $\mathrm{H}_{2} \mathrm{O}_{2}$ and $1,400 \mu \mathrm{L} 25 \mathrm{~mm}$ of sodium phosphate buffer. The decrease in the absorbance was recorded at $240 \mathrm{~nm}$, for $1 \mathrm{~min}$, by a spectrophotometer.

Superoxide dismutase activity was determined according to Giannopolitis \& Ries (1977), by measuring the ability of the enzyme extract to inhibit the photochemical reduction of nitro blue tetrazolium. The reaction mixture contained $100 \mu \mathrm{L}$ of $1 \mu \mathrm{M}$ riboflavin, $100 \mu \mathrm{L}$ of $12 \mathrm{mM}$ L-methionine, $100 \mu \mathrm{L}$ of $0.1 \mathrm{mM}$ EDTA (pH 7.8), $100 \mu \mathrm{L}$ of $50 \mathrm{mM}$ $\mathrm{Na}_{2} \mathrm{CO}_{3}(\mathrm{pH} 10.2), 100 \mu \mathrm{L}$ of $75 \mathrm{~mL}$ nitro blue tetrazolium in $2,300 \mu \mathrm{L}$ of $25 \mathrm{mM}$ sodium phosphate buffer (pH 6.8) and $200 \mu \mathrm{L}$ of crude enzyme extract, in a final volume of $3 \mathrm{~mL}$. Glass test tubes containing the reaction mixture were illuminated with a $120-\mathrm{W}$ fluorescent lamp, and identical tubes that were not illuminated served as blanks. After illumination for $15 \mathrm{~min}$, absorbance was measured at $560 \mathrm{~nm}$. Peroxidase enzyme activity was determined by the oxidation of guaiacol in the presence of $\mathrm{H}_{2} \mathrm{O}_{2}$ (Ghanati et al. 2002). The increase in absorbance at $470 \mathrm{~nm}$ was recorded in a spectrophotometer, for $1 \mathrm{~min}$. The reaction mixture contained $100 \mu \mathrm{L}$ crude extract, $500 \mu \mathrm{L} 5 \mathrm{mM} \mathrm{H}_{2} \mathrm{O}_{2}, 500 \mu \mathrm{L} 28 \mathrm{mM}$ guaiacol and $1,900 \mu \mathrm{L} 60 \mathrm{mM}$ potassium phosphate buffer (pH 6.1).

The relative water content was measured using the dry immersion method (Zhang et al. 2005). From each treatment, leaf discs were taken and weighted (fresh weight, Wf). After rehydrating for $24 \mathrm{~h}$ in the dark, the saturated weight (Ws) was obtained. Afterwards, leaf discs were oven-dried at $85{ }^{\circ} \mathrm{C}$, for $24 \mathrm{~h}$, for measurement of dry weight (Wd). The relative water content (RWC) was calculated as it follows: $\operatorname{RWC}(\%)=[(\mathrm{Wf}-\mathrm{Wd}) /(\mathrm{Ws}-\mathrm{Wd})] \times 100$.

All plants were uprooted at the maturity stage and then used for measuring the plant height, root length, number of pods, number of grains per pod, grain weight, grain yield and plant dry weight. Dry weight was determined by drying the plants in an oven, for $48 \mathrm{~h}$, at $85^{\circ} \mathrm{C}$.

Data were analysed by analysis of variance (Anova), using the GLM procedure of SAS (Version 9.0, Cary, NC, USA).

\section{RESULTS AND DISCUSSION}

Aspects of morphology and productivity, such as plant height, root length, number of pods per plant, number of grains per pod, 100-grain weight, final grain yield and dry weight, as well as physiological traits such as total chlorophyll, relative water content, proline and antioxidant enzyme activity, were significantly affected by water deficit treatments $(p<0.01)$ (Table 1). In addition, hexaconazole treatments significantly affected these variables $(p<0.01)$. A significant interaction between the water deficit and hexaconazole concentration was evident throughout the experiment. The main effect of year and the interaction of each treatment with year were not significant $(\mathrm{p}<0.01)$ (Table 1$)$.

Concerning plant height, the water stressed plants at R3 treated with hexaconazole (20 $\left.\mathrm{mg} \mathrm{L}^{-1}\right)$ showed a $27.70 \%$ reduction, if compared with the control treatment. The tallest plants were observed under complete irrigation conditions and no hexaconazole application (Figure 1a).

The results indicated that water deficit at R3 and R8 increased the root length about $5.64 \%$ and $6.98 \%$, respectively, when compared with the control treatment. Furthermore, the application of $20 \mathrm{mg} \mathrm{L}^{-1}$ of hexaconazole was associated with a significantly greater 
root length, as compared to $10 \mathrm{mg} \mathrm{L}^{-1}$ of hexaconazole, under water deficit conditions (Figure 1b).

The highest number of pods was obtained when plants were irrigated, i.e., under no stress, and treated with hexaconazole. Although water deficit at $\mathrm{R} 3$ and $\mathrm{R} 8$ reduced the total number of pods per plant by $3.45 \%$ and $14.05 \%$, respectively, a marked increase was observed due to the hexaconazole application (Figure 1c).

The number of grains per pod decreased $13.87 \%$ and $33.20 \%$, due to water deficit at R3 and $\mathrm{R} 8$, respectively. Irrespective of water deficit levels, the hexaconazole foliar application increased the number of grains per pod. The maximum value was obtained when plants were fully irrigated and sprayed with $20 \mathrm{mg} \mathrm{L}^{-1}$ of hexaconazole (Figure 1d).

A significant reduction in the 100-grain weight was found as a result of drought stress, particularly when irrigation was stopped at R8. Hexaconazole application caused a slight increase in grain weight, especially when applied under late water deficit conditions (Figure 1e).

Grain yield decreased as a result of drought stress at R3 and R8, when compared with the complete irrigation treatment $(\mathrm{p}<0.01)$. The results showed that plants treated with hexaconazole had higher grain yield, in relation to the non-treated plants grown under water deficit (Figure 1f).
Water deficit either at 60 DAS or 90 DAS reduced plant dry matter by $23.61 \%$ and $44.60 \%$, respectively. The maximum plant dry weight was obtained when plants were fully irrigated and treated with 10-20 $\mathrm{mg} \mathrm{L}^{-1}$ of hexaconazole (Figure $1 \mathrm{~g}$ ).

The results showed a significant reduction in the chlorophyll content $(15.46 \%)$ of plants grown under water deficit conditions, especially when irrigation stopped at R3. The application of hexaconazole on the plants did not significantly increase the chlorophyll content (Figure 2a).

Relative water content declined by $3.79 \%$ and $5.77 \%$, respectively due to water deficit at R3 and R8. By contrast, the hexaconazole application increased the relative water content in water stressed plants (1.49 \% and $2.81 \%$ ), however, it had no significant effect on well-watered plants (Figure $2 b$ ).

The proline accumulation increased by $200 \%$ and $300 \%$, as a consequence of water deficit. The maximum proline content was observed in plants stressed at the grain-filling stage treated with $20 \mathrm{mg} \mathrm{L}^{-1}$ of hexaconazole. The minimum proline content was observed in fully irrigated plants treated with $0 \mathrm{mg} \mathrm{L}^{-1}$ of hexaconazole (Figure 2c).

Antioxidant enzymes activity (superoxide dismutase, catalase and peroxidase) increased due to drought stress at both R3 and R8. However, the effect of stress at the grain-filling stage (90 DAS)

Table 1. Analysis of variance of common bean traits with respect to water deficit and hexaconazole foliar application treatments.

\begin{tabular}{|c|c|c|c|c|c|c|c|c|}
\hline Source of variation & d.f & $\begin{array}{l}\text { Plant } \\
\text { height }\end{array}$ & $\begin{array}{l}\text { Root } \\
\text { length }\end{array}$ & $\begin{array}{l}\text { Number of } \\
\text { pods }\end{array}$ & $\begin{array}{c}\text { Number of } \\
\text { grains per pod }\end{array}$ & $\begin{array}{c}\text { 100-grain } \\
\text { weight }\end{array}$ & $\begin{array}{l}\text { Grain } \\
\text { yield }\end{array}$ & $\begin{array}{c}\text { Dry } \\
\text { weight }\end{array}$ \\
\hline Year & 1 & ns & ns & ns & ns & ns & ns & ns \\
\hline Drought & 2 & $* *$ & $* *$ & $* *$ & $* *$ & $* *$ & $* *$ & $* *$ \\
\hline Hexaconazole & 2 & $* *$ & $* *$ & $* *$ & $* *$ & $* *$ & $* *$ & $* *$ \\
\hline Year $\times$ drought & 2 & ns & ns & ns & ns & ns & ns & ns \\
\hline Year $\times$ hexaconazole & 2 & ns & ns & ns & ns & ns & ns & ns \\
\hline Drought $\times$ hexaconazole & 4 & $* *$ & $* *$ & $* *$ & $* *$ & $* *$ & $* *$ & $* *$ \\
\hline Year $\times$ drought $\times$ hexaconazole & 4 & ns & ns & ns & ns & ns & ns & ns \\
\hline Error & 32 & 0.892 & 0.041 & 0.126 & 0.03 & $12,828.61$ & $6,730.60$ & $17,388.55$ \\
\hline $\mathrm{CV}(\%)$ & & 2.70 & 1.90 & 4.60 & 3.78 & 8.76 & 6.16 & 5.19 \\
\hline Source of variation & d.f & Chlorophyll & RWC & Proline & SOD & CAT & POX & \\
\hline Year & 1 & $\mathrm{~ns}$ & ns & ns & $\mathrm{ns}$ & ns & ns & \\
\hline Drought & 2 & $* *$ & $* *$ & $* *$ & $* *$ & $* *$ & $* *$ & \\
\hline Hexaconazole & 2 & $* *$ & $* *$ & $* *$ & $* *$ & $* *$ & $* *$ & \\
\hline Year $\times$ drought & 2 & ns & ns & ns & ns & ns & ns & \\
\hline Year $\times$ hexaconazole & 2 & ns & ns & ns & ns & ns & ns & \\
\hline Drought $\times$ hexaconazole & 4 & $* *$ & $* *$ & $* *$ & $* *$ & $* *$ & $* *$ & \\
\hline Year $\times$ drought $\times$ hexaconazole & 4 & ns & ns & ns & ns & ns & ns & \\
\hline Error & 32 & 0.0005 & 0.112 & 0.000003 & 101.59 & 18.62 & 30.23 & \\
\hline $\mathrm{CV}(\%)$ & & 1.06 & 0.462 & 7.57 & 1.58 & 3.49 & 4.28 & \\
\hline
\end{tabular}




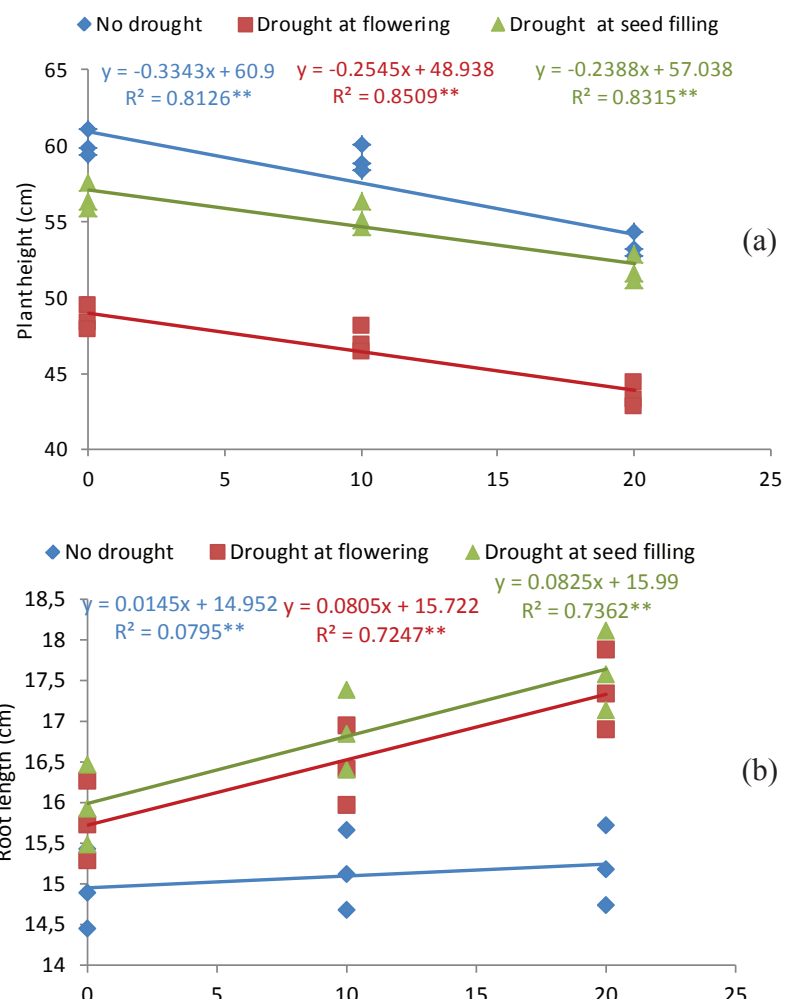

was more pronounced when compared with fully irrigated plants. Similarly, hexaconazole treatments significantly increased the antioxidant enzymes activity under both stress conditions, however, no changes were observed under full irrigation (Figures 2d, 2e and 2f).

Hexaconazole is an active member of the triazole family, with plant growth regulating properties (Jaleel et al. 2007). It can cause many morphological and physiological changes, such as
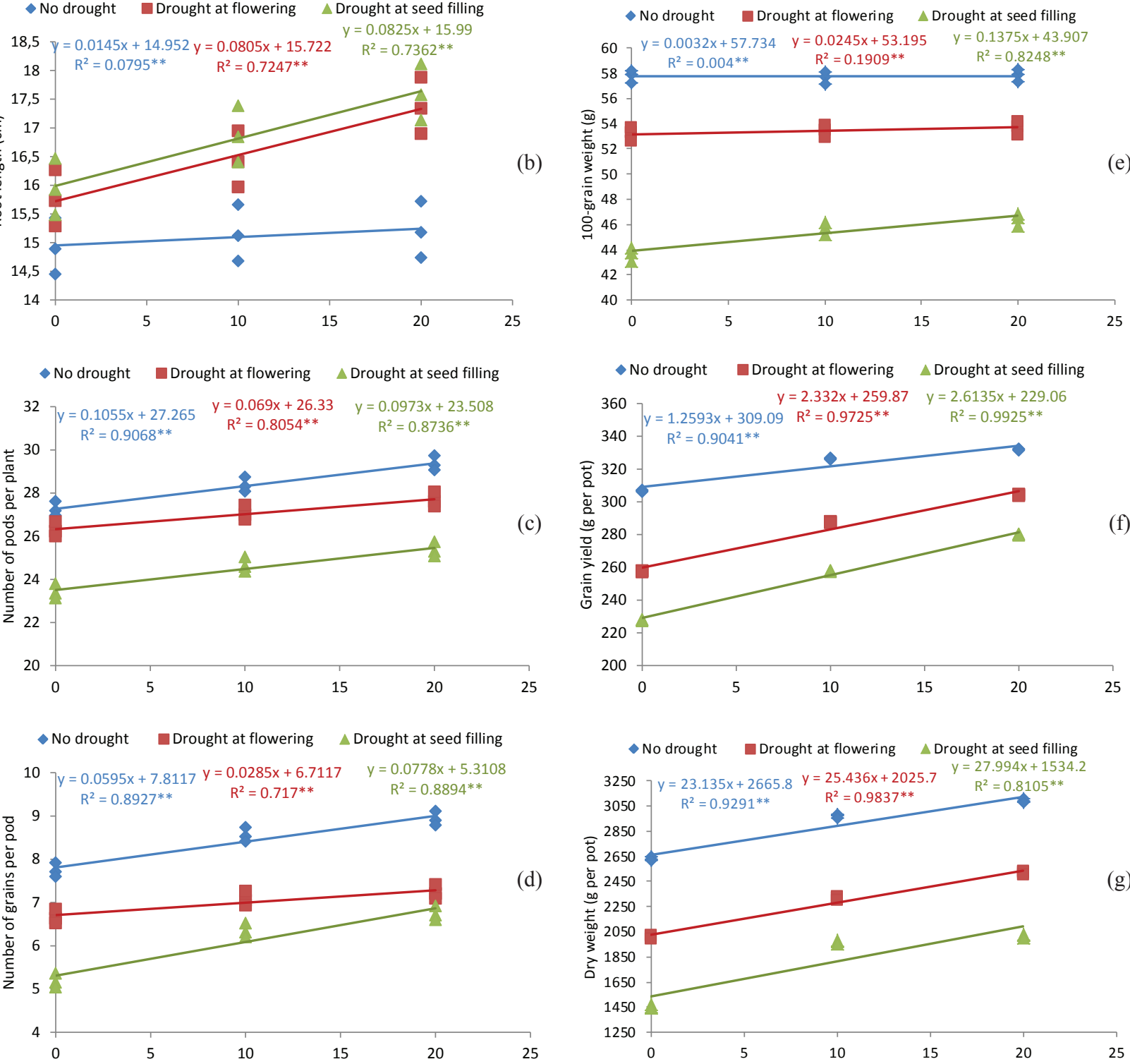

Hexaconazole concentration (mg L $\left.\mathrm{L}^{-1}\right)$

Figure 1. Linear regression demonstrating the effect of hexaconazole concentrations and irrigation treatments on different agronomic traits: plant height (a), root length (b), number of pods per plant (c), number of grains per pod (d), 100-grain weight (e), grain yield (f) and dry weight $(\mathrm{g})$. Linear regressions were adjusted for the fully irrigated treatment (blue), for drought stress at the flowering stage (red) and for drought stress at the seed-filling stage (green) conditions. 
reducing shoot growth and stimulating root growth (Jaleel et al. 2006, Johnson et al. 2008, Navarro et al. 2009). The increase in root growth may be related to the increased partitioning of assimilates toward the roots, due to a decreased demand on the shoot of triazole treated plants (Symons et al. 1990). Similar results were found by Navarro et al. (2009), who showed that hexaconazole can stimulate root growth.

The effect of water deficit on both the vegetative and reproductive phases of crops, including on yield, has been studied under field and glasshouse conditions. In general, crop yield depends on the accumulation of photo-assimilates during the growing period and the way they are partitioned between desired storage organs of the plant. Davies et al. (2000) and Leport et al. (2006) showed flower and pod abortion, along with reduced pod and seed production, as well as limited chickpea seed yield, due to water stress at the flowering and seed-filling stages.
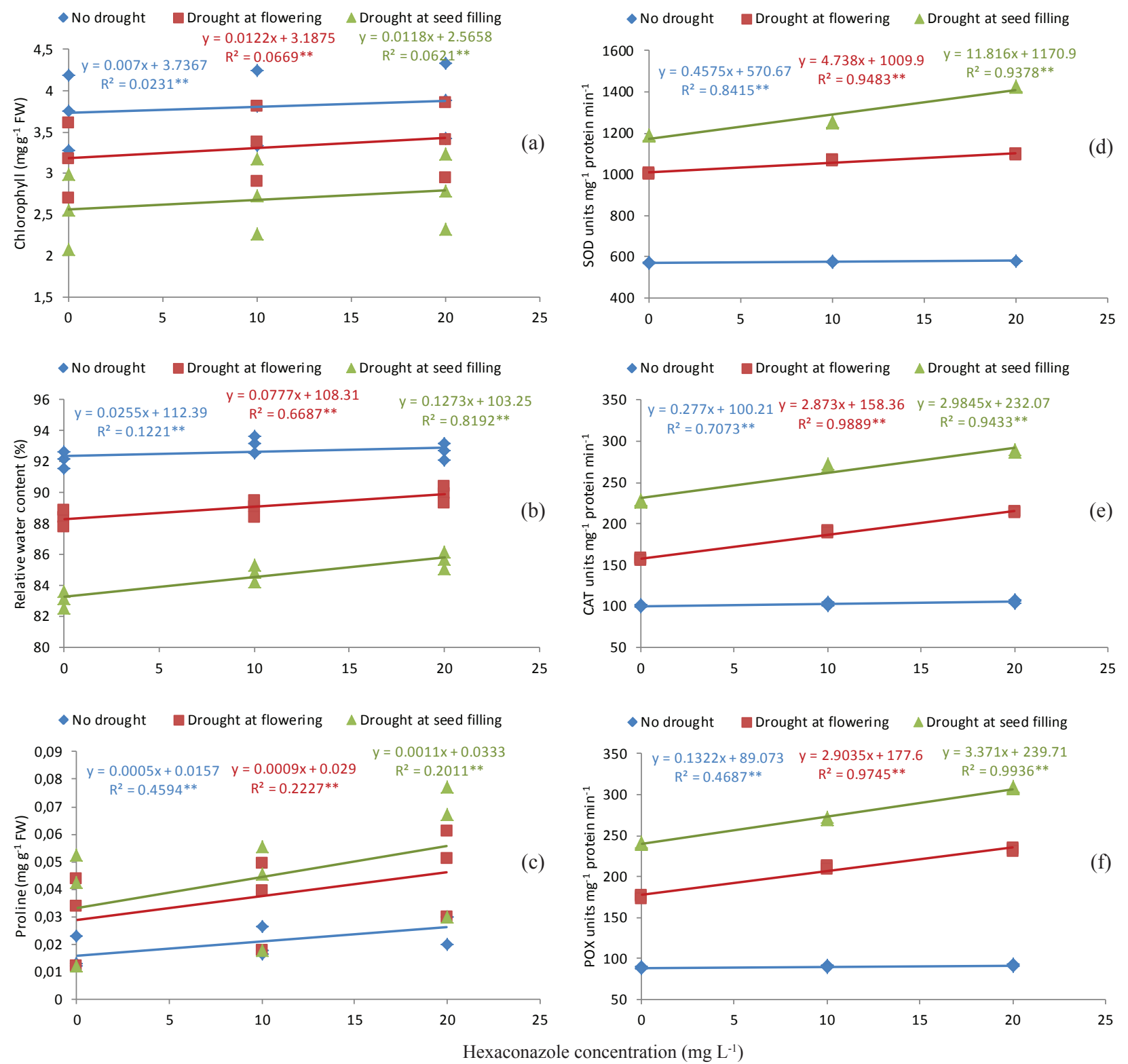

Figure 2. Linear regression demonstrating the effects of hexaconazole concentrations and irrigation treatments on physiological traits: chlorophyll content (a), relative water content (b), proline (c), superoxide dismutase activity (d), catalase activity (e) and peroxidase activity (f). Linear regressions were adjusted for the fully irrigated treatment (blue), for drought stress at the flowering stage (red) and for drought stress at the seed-filling stage (green) conditions. 
In the present study, the hexaconazole foliar application increased the number of pods and grains, what contributed for a higher grain yield, if compared to the control. In other words, the increase in grain yield was mainly due to the increase in the number of pods and grains rather than to grain weight. Gawade et al. (2009) also reported a similar effect in soybean. In addition, previous studies showed that the differentiation of the apical meristem can be inhibited by triazoles (Serrani et al. 2010). Thus, hexaconazole may stimulate the axillary bud emergence and improve the effective branch formation, resulting in more pods. However, a detailed discussion regarding the influence of hexaconazole on grain formation and grain size has not yet been well documented for legumes.

Drought stress decreased the dry weight, when compared to control plants. Water deficit decreases photosynthesis, assimilation and finally growth (Liang et al. 2006). Among the common adverse effects of water stress on crop plants, the reduction in fresh and dry biomass production can be pointed out (Farooq et al. 2009). The hexaconazole application increased the plant dry weight either in fully irrigated or water stressed plants. An increase in dry weight in other plants has been previously reported (Jenks et al. 2001, Mohamadi \& Rajaei 2013). The alteration of hormonal status and increased photosynthesis induced by hexaconazole might be the cause for the increased dry weight under water deficit conditions. The improvement in the chlorophyll content, due to the hexaconazole application, is the main contribution for a better yield, regardless of water conditions (Leul \& Zhou 1999, Zhou \& Leul 1999, Chen \& Gallie 2004).

These results correlate well with the findings of Zhang et al. (2007), who showed that the treatment of soybean (Glycine max Merr.) plants with uniconazole, a compound closely related to triazole, resulted in higher levels of biomass production, if compared with non-treated plants under water deficit. Similar results have also been reported by Jaleel et al. (2008), who stated that the protection conferred by propiconazole, another triazole compound, on Madagascar periwinkle (Catharanthus roseus L.) plants against salinity was evident. They observed that plants treated with propiconazole had higher biomass production and growth variables, when compared to non-treated plants, under water deficit.
The reduction in the chlorophyll content under water deficit is due to the destruction of chlorophyll pigments and the instability of the pigment-protein complex (Levitt 1980). This can occur due to the inhibition of enzymes involved in the chlorophyll biosynthesis or to the preferential synthesis of proline, which requires glutamate, a precursor of chlorophyll. A reduction in chlorophyll content was reported in water stressed soybean (Zhang et al. 2006), wheat (Nayyar \& Gupta 2006) and cotton (Massacci et al. 2008).

The increased chlorophyll content under hexaconazole treatment might be due to the ability of hexaconazole to enhance chlorophyll biosynthesis (Fletcher et al. 2000). The increased chlorophyll content is also attributed to more densely packed chloroplasts in a small leaf area (Divya-Nair et al. 2009). Relative water content is the appropriate measurement of plant water status, in terms of physiological consequence of cellular water deficit, while water potential is an estimate of plant water status and is useful for dealing with water transport in the soil-plant-atmosphere continuum (Kramer 1988). The decrease in relative water content, in plants grown under water deficit conditions, depends on plant vigour reduction and has been observed in many species (Liu et al. 2002). Under water deficit conditions, cell membranes are subjected to changes such as penetrability and decrease in sustainability (Blokhina et al. 2003).

Proline accumulation is a common physiological response to water deficit in many plants. This highly water-soluble amino acid protects membranes against the harmful effects of high concentrations of inorganic ions, and it can also function as both a protein-compatible hydrotrope and as a hydroxyl radical scavenger (Smirnoff \& Cumbes 1989). In the current study, it was found that the hexaconazole treatment markedly caused a drastic accumulation of proline in common bean leaves. This result was also observed by Verslues (2006). The accumulation of proline in leaves most likely keep the osmotic balance under water deficit, resulting in water tolerance improvement. Induction and stimulation of proline accumulation have been regarded as a strategy to improve plant tolerance to stresses. The osmolyte accumulation, which is induced by triazole compounds, may be an important factor to prevent water loss and maintain high photosynthesis activity in plants (Zhang et al. 2007). 
Triazole compounds such as hexaconazole have been shown to improve the tolerance of water stressed plants, possibly due to an improved antioxidative defense mechanism, with higher activities of superoxide dismutase, catalase and peroxidase enzymes that scavenge reactive oxygen species and decrease lipid peroxidation and membrane deterioration (Hojati et al. 2011). The current results are similar to those found by Zhang et al. (2007), who revealed that uniconazole, a compound closely related to triazole, resulted in higher antioxidant enzyme activity in soybean. Similar results were also reported by Jaleel et al. (2008), who stated the protection conferred by propiconazole to C. roseus plants. There is an increasing evidence that the stress protection by hexaconazole is mediated by a reduction in the free radicals damage and an increase in the antioxidant potential. From these findings, it can be concluded that hexaconazole moderately alleviates the effect of water deficit in common bean plants and increases the antioxidant enzyme activities that protect them against free radical damage, thus mediating the tolerance to water deficit.

\section{CONCLUSIONS}

1. Hexaconazole application improves the tolerance of common bean plants to water deficit;

2. Hexaconazole foliar application leads to higher growth and yield components under water deficit conditions;

3. Hexaconazole improves relative water content under water deficit stress conditions and promotes antioxidant enzyme activity to scavenge the oxidative stress caused by water deficit stress.

\section{REFERENCES}

AHMAD, P. et al. Oxidative stress: role of antioxidants in plants. New Delhi: Studium Press, 2011.

AHMAD, P. et al. Roles of enzymatic and non-enzymatic antioxidants in plants during abiotic stress. Critical Review in Biotechnology, v. 30, n. 3, p. 161-175, 2010.

ARNON, D. I. Copper enzymes in isolated chloroplast: polyphenol oxidase in Beta vulgaris L. Plant Physiology, v. 24, n. 1, p. 1-50, 1949.

BANNAYAN, M. et al. Yield and seed quality of Plantago ovata and Nigella sativa under different irrigation treatments. Industrial Crops and Products, v. 27, n. 1, p. 11-16, 2008.
BATES, L. S.; WALDERN, R. P.; TEAVE, I. D. Rapid determination of free proline for water stress studies. Plant and Soil, v. 39, n. 1, p. 205-207, 1973.

BLOKHINA, O.; VIROLAINEN, E.; FAGERSTEDT, K. V. Anti-oxidative damage and oxygen deprivation stress. Annual Botany, v. 91, n. 2, p. 179-194, 2003.

BOHNERT, H. J.; JENSEN, R. G. Strategies for engineering water stress tolerance in plants. Trends in Biotechnology, v. 14, n. 3, p. 89-97, 1996.

CAKMAK, I.; HORST, W. Effect of aluminium on lipid peroxidation, superoxide dismutase, catalase and peroxidase activities in root tip of soybean (Glysin max). Physiologia Plantarum, v. 83, n. 3, p. 463-468, 1991.

CHEN, Z.; GALLIE, D. R. The ascorbic acid redox state controls guard cell signalling stomatal movement. The Plant Cell, v. 16, n. 5, p. 1143-1162, 2004.

DASH, S.; MOHANTY, N. Evaluation of assays for the analysis of thermo tolerance and recovery potentials of seedlings of wheat (Triticum aestivum L.) cultivars. Journal of Plant Physiology, v. 158, n. 9, p. 1153-165, 2001.

DAVIES, S. L. et al. Remobilization of carbon and nitrogen supports seed filling in chickpea subjected to water deficit. Australian Journal of Agricultural Research, v. 51, n. 7, p. 855-866, 2000.

DIVYA-NAIR, V. et al. Changes in growth and photosynthetic characteristics of Ocimum sanctum under growth regulator treatments. Frontiers of Biology in China, v. 4, n. 2, p. 192-199, 2009.

FAROOQ, M. et al. Plant drought stress: effects, mechanisms and management. Agronomy for Sustainable Development, v. 29, n. 1, p. 185-212, 2009.

FLETCHER, R. A. et al. Triazoles as plant growth regulators and stress protectants. Horticultural Reviews, v. 24 , n. 1 , p. $55-138,2000$.

GAWADE, D. B. et al. Field evaluation of fungicides, botanicals and bio-agents against anthracnose of soybean. Agricultural Science Digest, v. 29, n. 3, p. 174-177, 2009.

GHANATI, F.; MORITA, A.; YOKOTA, H. Induction of suberin and increase of lignin content by excess boron in tobacco cell. Soil Science and Plant Nutrition, v. 48, n. 3, p. 357-364, 2002.

GIANNOPOLITIS, C.; RIES, S. Superoxide dismutase occurrence in higher plant. Plant Physiology, v. 59, n. 2, p. 309-314, 1977. 
HASAN, S. A. et al. 28-Homobrassinolide protects chickpea (Cicer arietinum) from cadmium toxicity by stimulating antioxidants. Environmental Pollution, v. 151, n. 1, p. 60-66, 2008.

HAYAT, S. et al. Brassinosteroid enhanced the level of antioxidants under cadmium stress in Brassica juncea. Environmental and Experimental Botany, v. 60, n. 1, p. 33-41, 2007.

HOJATI, M. et al. Hexaconazole induces antioxidant protection and apigenin-7-glucoside accumulation in Matricaria chamomilla plants subjected to drought stress. Journal of Plant Physiology, v. 168, n. 8, p. 782-791, 2011.

JALEEL, C. A. et al. Soil applied propiconazole alleviates the impact of salinity on Catharanthus roseus by improving antioxidant status. Pesticide Biochemistry and Physiology, v. 90, n. 2, p. 135-139, 2008.

JALEEL, C. A. et al. TDM Triadimefon induced changes in the antioxidant metabolism and ajmalicine production in Catharanthus roseus L. G. Don. Plant Science, v. 171, n. 2, p. 271-276, 2006.

JALEEL, C. A. et al. Changes in biochemical constituents and induction of early sprouting by triadimefon treatment in white yam (Dioscorea rotundata Poir.) tubers during storage. Journal of the Zhejiang University Science B, v. 8, n. 4, p. 283-288, 2007.

JENKS, M. A. et al. Leaf cuticular waxes of potted rose cultivars as affected by plant development, drought and paclobutrazol treatments. Physiologia Plantarum, v. 112, n. 1, p. 62-70, 2001.

JOHNSON, I. et al. Influence of hexaconazole on biochemical constituents of groundnut. The Korean Journal of Pesticide Science, v. 12, n. 4, p. 335-341, 2008.

KRAMER, P. J. Measurement of plant water status: historical perspectives and current concerns. Irrigation Science, v. 9, n. 4, p. 275-287, 1988.

LEPORT, L. et al. Variation in pod production and abortion among chickpea cultivars under terminal drought. European Journal of Agronomy, v. 24, n. 3, p. 236-246, 2006.

LEUL, M.; ZHOU, W. J. Alleviation of water logging damage in winter rape by uniconazole application: effects on enzyme activity, lipid peroxidation, and membrane integrity. Journal of Plant Growth Regulation, v. 18, n. 1, p. 9-14, 1999.
LEVITT, J. Responses of plants to environmental stresses. New York: Academic Press, 1980.

LIANG, Z. S. et al. Investigation on water consumption characteristics and water use efficiency of poplar under soil water deficits on the Loess Plateau. Colloids and Surfaces B: Biointerfaces, v. 53, n. 1, p. 23-28, 2006.

LIU, Y.; FISKUM, G.; SCHUBERT, D. Generation of reactive oxygen species by mitochondrial electron transport chain. Journal of Neurochemistry, v. 80, n. 5, p. 780-787, 2002.

MAKUNDE, G.; POMPI, A. AREX. Harare: Agronomy Research Institute, 2004.

MANIVANNAN, P. et al. Growth, biochemical modifications and proline metabolism in Helianthus annuus L. as induced by drought stress. Colloids and Surfaces B: Biointerfaces, v. 59, n. 2, p. 141-149, 2007.

MASSACCI, A. et al. Response of the photosynthetic apparatus of cotton (Gossypium hirsutum) to the onset of drought stress under field conditions studied by gas exchange analysis and chlorophyll fluorescence imaging. Plant Physiolgy and Biochemistry, v. 46, n. 2, p. 189-195, 2008.

MOHAMADI, N.; RAJAEI, P. Effect of triamidefon fungicide on some growth parameters and antioxidant enzymes activity in tomato (Lycopersicom esculentum Mill.) plant under drought stress. International Journal of Advanced Biology and Biomedical Research, v. 1, n. 1, p. 341-350, 2013.

NAVARRO, A. et al. The influence of mycorrhizal inoculation and paclobutrazol on water and nutritional status of Arbutus unedo L. Environmental and Experimental Botany, v. 66, n. 3, p. 362-371, 2009.

NAYYAR, H.; GUPTA, D. Differential sensitivity of $\mathrm{C}_{3}$ and $\mathrm{C}_{4}$ plants to water deficit stress: association with oxidative stress and antioxidants. Environmental and Experimental Botany, v. 58, n. 1, p. 106-113, 2006.

NGOUAJIO, M.; WANG, G.; GOLDY, R. Withholding of drip irrigation between transplanting and flowering increases the yield of field-grown tomato under plastic mulch. Agriculture Water Management, v. 87, n. 3, p. 285 291, 2007.

REDDY,A. R.; CHAITANYA, K. V.; VIVEKANANDAN, M. Drought induced responses of photosynthesis and antioxidant metabolism in higher plants. Journal of Plant Physiology, v. 161, n. 11, p. 1189-1202, 2004. 
REISDORPH, N. A.; KOSTER, K. Progressive loss of desiccation tolerance in germinating pea (Pisum sativum) seeds. Physiologia Plantarum, v. 105, n. 2, p. 266-271, 1999.

SÁNCHEZ-RODRÍGUEZ, E. et al. Antioxidant response resides in the shoot in reciprocal grafts of drought-tolerant and drought-sensitive cultivars in tomato under water stress. Plant Science, v. 188-189, n. 1, p. 89-96, 2012.

SCHWARTZ, H. F. et al. (Eds.). Dry bean production and pest management. St. Paul: The American Phytopathological Society, 1996.

SERRANI, J. C. et al. Inhibition of auxin transport from the ovary or from the apical shoot induces parthenocarpic fruitset in tomato mediated by gibberellins. Plant Physiology, v. 153, n. 2, p. 851-862, 2010.

SMIRNOFF, N.; CUMBES, Q. J. Hydroxyl radical scavenging activity of compatible solutes. Phytochemistry, v. 28, n. 4, p. 1057-1060, 1989.

SYMONS, P. R. R.; HOFMAN, P. J.; WOLSTENHOLME, B. N. Responses to paclobutrazol of potted 'Hass' avocado trees. Acta Horticulture, v. 275, n. 21, p. 193198, 1990 .
TAN, Y. et al. Effect of water deficits on the activity of anti-oxidative enzymes and osmoregulation among three different genotypes of Radix astragali at seedling stage. Colloids and Surfaces B: Biointerfaces, v. 49, n. 1, p. 6065, 2006.

VERSLUES, P. E. Methods and concepts in quantifying resistance to drought, salt and freezing, abiotic stresses that affect plant water status. The Plant Journal, v. 45, n. 4, p. 523-539, 2006.

ZHANG, J. et al. Role of ABA in integrating plant responses to drought and salt stresses. Field Crops Research, v. 297, n. 1, p. 111-119, 2006.

ZHANG, J. et al. The relationship between water use efficiency and related physiological traits in wheat leaves. Acta Agronomica Sinica, v. 31, n. 2, p. 1593-1599, 2005.

ZHANG, M. et al. Uniconazole induced tolerance of soybean to water deficit stress in relation to changes in photosynthesis, hormones and antioxidant system. Journal of Plant Physiology, v. 164, n. 6, p. 709-717, 2007.

ZHOU, W. J.; LEUL, M. Uniconazole-induced tolerance of rape plants to heat stress in relation to changes in hormonal levels, enzyme activities and lipid peroxidation. Plant Growth Regulation, v. 27, n. 2, p. 99-104, 1999. 